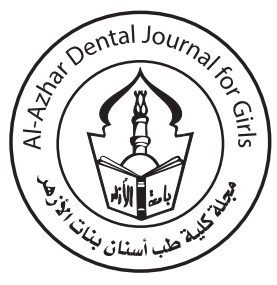

\title{
Histopathological Changes after Direct Pulp Capping in Dogs with Bioactive Glass Incorporated in Resin Composite and Adhesive
}

\author{
Heba A. Arafa ${ }^{1 *}$, Maha A. Niazy ${ }^{2}$, Amr Albolok $^{3}$, Mona Eissa ${ }^{4}$, Mohamed Abd-Elmoaty
}

Codex : 02/21.10

azhardentj@azhar.edu.eg

http://adjg.journals.ekb.eg

DOI: 10.21608/adjg.2021.36688.1278

Restorative Dentistry

(Removable Prosthodontics, Fixed

Prosthodontics, Endodontics, Dental Biomaterials, Operative Dentistry)

\section{KEYWORDS}

Bioactive glass, direct pulp capping, hard tissue, Calcium Hydroxide.

\begin{abstract}
Purpose: To evaluate histopathologically the dental pulp response to bioactive glass nanoparticles in the resin composite restoration and the adhesive as a direct pulp capping material regarding inflammatory cell infiltrate, hard tissue formation and Pulp tissue disorganization. Material and methods: Four mongrel male dogs were selected for this study with a total of 40 teeth were divided into two groups $(n=20)$ according to the treatment protocol (P); (P1) treated with light cured calcium hydroxide (control group) and (P2): treated with resin composite and its adhesive containing bioactive glass. The histopathological findings were studied for each specimen at two times intervals (T); (T1) fourteen days and (T2) sixty days. Split mouth technique was followed. The manufacturer's instructions were followed during applying the materials. Animals were sacrificed at each time interval and teeth were collected for histopathological finding. Results: adhesive and resin composite restoration containing bioactive glass group showed significantly less inflammatory cell infiltrate, less pulp tissue disorganization and better calcific bridge formation than Calcium hydroxide group. When the effect of time was considered, inflammation was significantly decreased from fourteen days to sixty days while hard tissue formation was significantly increased for both materials. Also pulp tissue disorganization was decreased significantly and showed more normal pulp tissue morphology from fourteen days and to sixty days. Conclusion: resin composite restoration and its adhesive containing nanoparticles of bioactive glass could be used as a direct pulp capping material.
\end{abstract}

- Paper extracted from Doctor thesis titled "Clinical Response of Human Pulp Capped with Bioactive Glass Incorporated in Resin Composite and Adhesive and Histopathological Changes after Direct Pulp Capping in Dogs"

1. Assistant lecturer in Operative Dentistry Department, Faculty of Dentistry, Beni Suef University, Egypt.

2. Professor of Operative Dentistry, Faculty of Dental Medicine for Girls, Al-Azhar University, Cairo, Egypt.

3. Professor and head of oral and maxillofacial pathology, Minia university, Egypt.

4. Associate Professor of Operative Dentistry, head of Operative Dentistry department, Faculty of Dentistry, Beni-Suef University, Egypt.

5. Associate professor of Operative Dentistry, Faculty of Dentistry, Sinai University kantara branch, Egypt.

* Corresponding author email: dr_heba_1999@hotmail.com 


\section{INTRODUCTION}

The operative treatment of deep carious lesions can be challenging due to risk of pulp exposure during excavation which can reduce the probability of pulp survival ${ }^{(1)}$. Direct pulp capping is aiming to save pulpal health and function. The critical factor for successful pulp capping is the selection of the capping material that preserves the pulp health and vitality. In the $18^{\text {th }}$ century, Philip Pfaff performed the first pulp capping ever, using a small piece of gold for the healing of exposed vital pulp. According to the literature from past to present, different pulp capping materials have been used, one of them is $\mathrm{Ca}(\mathrm{OH})_{2}{ }^{(2)} \cdot \mathrm{Ca}(\mathrm{OH})_{2}$ was used as pulp capping material in conservative dentistry, when comes in direct contact with vital pulp tissues causes a small area of necrosis followed by a mild inflammatory reaction. However, using $\mathrm{Ca}(\mathrm{OH})_{2}$ has shown a clear tendency towards dissolution by time leading to spaces that could be a suitable way bacterial invasion $^{(3)}$.

Consequently, there is a great need to develop new bioactive materials that help in avoiding the growth microbes through its antibacterial action allowing to have an environment free of bacteria during healing and regenerating the defective area ${ }^{(4)}$. Bioactive glass is now available in the market and shows low cytotoxicity to dental pulp cell and antimicrobial activity against intra-oral bacteria ${ }^{(5)}$. Bioactive glass material has several unique properties, the most important one is the ability to act as a biomimetic mineralizer that can match the mineralizing traits of the body itself. In addition, it can affect cell signals in a beneficial way for the tissue structure and function restoration. It is also seen as a breakthrough in remineralization technology ${ }^{(6)}$.

The nanoparticulate form of bioactive glass (BGNs) has better bioactivity and higher ability to enhance dentin mineralization process compared to normal sized particles ${ }^{(7)}$. It was also found that nanoparticles exhibit better mechanical properties and have more ability to penetrate into dentinal tubules which improve the poor adhesion qualities of different dental pulp capping materials compared to normal sized particles ${ }^{(8)}$. In the past two decades extensive research on bioactive and remineralizing resin composites based on bioactive glass (BG) indicates their attractiveness as a possible solution for the prevention of secondary caries which is considered one of the primary causes of failure of contemporary composite restorations $\mathrm{s}^{(9)}$.

Moreover, experimental composites and their adhesive systems based on bioactive glass (BG) especially nanoparticle form offer multiple benefits, originating from their potential for remineralization and reduction of bacterial penetration which can improve the longevity of the dentin bonding ${ }^{(10)}$.These properties encouraged researchers to study its effect on several aspects in dentistry ${ }^{(11)}$.

Therefore, the aim of this research was to evaluate the pulpal tissue response after pulp capping procedures in dog teeth using bioactive glass.

The study was conducted to accept or reject the null hypothesis that:

There is no difference in the response of dogs teeth (in terms of inflammatory cell infiltrate, pulp tissue disorganization and dentin bridge formation) to bioactive glass nanoparticles incorporated in resin composite restoration and its adhesive when compared with light cured calcium hydroxide.

\section{MATERIAL AND METHODS}

Ethical approval was granted by Committee in the Faculty of Dentistry Al-Azhar University number (rec16-071).

\section{Preparation of bioactive glass particles:}

Bioactive glass nanoparticles were prepared at Nanostreams Company (Science, Technology \& Engineering in $6^{\text {th }}$ of October City, nanostreams@ gmail.com). Bioglass NS0001 (Nanostreams, Egypt) was prepared using alkoxide sol gel technique. The chemical composition includes $45 \% \mathrm{SiO}_{2}, 25 \% \mathrm{CaO}$, 
$25 \% \mathrm{Na}_{2} \mathrm{O}$ and $5 \% \mathrm{P}_{2} \mathrm{O}_{5}$. The oxide composition was prepared using silicon and phosphorous alkoxides together with sodium salt as sodium hydroxide and $\mathrm{Ca}$ - salt as Calcium hydroxide. Deionized water and ethanol alcohol were used as solvents. The gel was prepared at $70^{\circ} \mathrm{C}$ and $\mathrm{pH} \sim 2$ then it was aged for a week to complete the reaction and then heat treated at different temperature up to $800^{\circ} \mathrm{C}$.

\section{Characterization of bioactive glass particles:}

Bioactive glass nanoparticles were analyzed using X-ray diffraction (XRD) analysis and Transmission Electron Microscope (TEM). XRD analysis confirms amorphous structure with particle size of less than $20 \mathrm{nms}$.

\section{Preparation of treatment materials:}

\section{a. Tetric N-ceram:}

The bioglass nanoparticles prepared for use as filler were first incubated in the drier at $100^{\circ} \mathrm{C} / 30$ minutes and then cooled to room temperature to facilitate particle dispersion and homogenous distribution in composite. All procedures were done in dark clean room as the Tetric N Ceram is light sensitive composite. Four trial small samples of Tetric $\mathrm{N}$ Ceram Resin (about $0.2 \mathrm{gm}$ ) were first tested as trial for mixing with bioglass nanoparticles (less than $20 \mathrm{nms}$ in size). The trial was successful to incorporate $5 \%$ of bioglass nanoparticles in the composite. Extra bioglass was found to affect the functional properties of the composite. The physical appearance; workability and consistency were found more or less similar to bioglass filler of up to $5 \%{ }^{(12)}$.

\section{b. Tetric N-bond:}

The liquid polymeric adhesive was mixed with the required content of bioglass nanoparticles using a drill grinder together with ultrasonic waves for a time of 10 minutes; the time required for good mixing without the decomposition of the polymer structure $^{(13)}$. Then the final resins were tested for 40 seconds using LED light to assure of the composite quality. The best setting time for the resulted product is 40 seconds. The distribution of the bioglass nanoparticles in the resin composite restoration and the adhesive was evaluated by transmission electron microscope TEM and scanning electron microscope SEM. The samples were coated with a thin layer of Gold $(\mathrm{Au})$ by sputtering and examined by scanning electron microscope model Quanta 250 FEG (Field Emission Gun) ${ }^{(14)}$.

\section{Selection of samples:}

Four mongrel male dogs apparently health without any signs of lameness were selected for the study. Their mean age was $20.66 \pm 0.88$ months, the mean weights were $20.29 \pm 0.45 \mathrm{~kg}$. Maxillary and mandibular canines, second, third, fourth premolars and first molar teeth were selected for the treatment with a total of 40 teeth ${ }^{(8)}$.

\section{Preoperative procedure:}

The dogs were subcutaneously injected with atropine sulphate at a dose rate of $0.04 \mathrm{mg} / \mathrm{Kg}$ body weight 15 minutes prior to the induction of anaesthesia to reduce salivation and counteract any possible arrythmia. A cannula ${ }^{(18-20)}$ gauge was fixed in the cephalic vein for each dog and used for injection of anesthetic solution (mixture of xylazine $1.0 \mathrm{mgKg}$ body weight in combination with ketamine hydrochloride $5.0 \mathrm{mg} / \mathrm{Kg}$ body weight) and the anesthesia was maintained throughout the operative procedure by using intra muscular injection of $6 \mathrm{mg} / \mathrm{Kg}$ theopentone. $2.0 \mathrm{mg} / \mathrm{Kg}$ body weight throughout the cannula $^{(15)}$.

\section{Grouping of teeth:}

A total of 40 teeth (four dogs) were divided into two groups $(n=20)$ according to the treatment protocol (P); (P1) treated with light cured calcium hydroxide (control group) and (P2): treated with resin composite and its adhesive containing bioactive glass. The histopathological findings were studied for each specimen at two time intervals (T); (T1) fourteen days and (T2) sixty days. 


\section{Treatment procedures:}

Each dog was placed on the operating table in supine position with tilted heads to keep the respiratory airway unblocked. The whole procedures were done under proper aseptic condition using sterile instruments and the teeth were disinfected with chlorohexidine $0.5 \%$. Special mouth opener was used to maintain the mouth opening to the desired width for better accessibility. Sterile towels were used to cover all the undesired area of dog for better visual concentration ${ }^{(16)}$.

After proper isolation with rubber dam, Class V cavities were prepared on the buccal surface of the selected teeth $2 \mathrm{~mm}$ away from the gingival margin ( $2 \mathrm{~mm}$ in width, $3 \mathrm{~mm}$ in length and $2 \mathrm{~mm}$ in depth) using inverted-cone carbide bur (Mani, Germany) assembled on low speed micromotor (Strong, SBLS4C-022A, Korea) at speed of $25000 \mathrm{rpm}$ under sterile copious cooling working intermittent to avoid excessive heat generation. A new bur was used for every fourth tooth to ensure cutting efficiency. Pulp exposure was performed in the middle of the cavity floor using a round carbide bur \# $1^{(8)}$. Fig 1 ( $a$ and b)

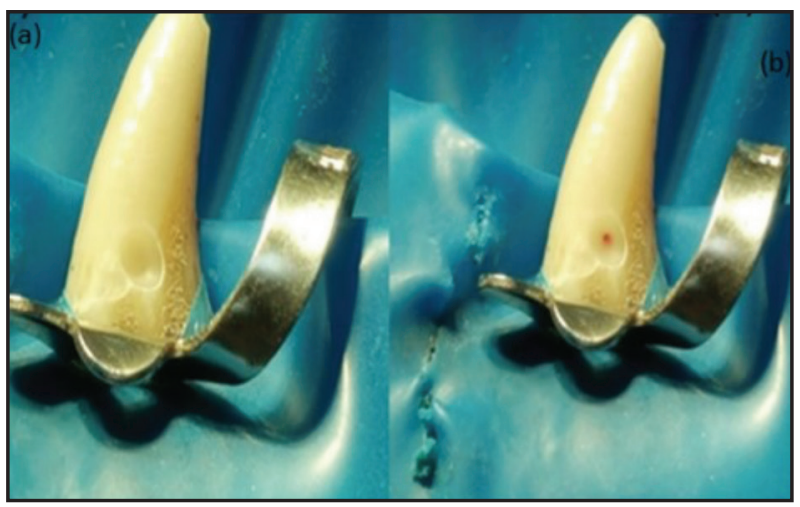

Figure (1) a) Isolation and class $\mathrm{V}$ cavity preparation b) Exposure site for preparation

Immediately after pulp exposure, dentin chips were washed out with sterile saline solution and light pressure with sterile cotton pellets was used until haemostasis occurred ${ }^{(17)}$. Split mouth technique was used; the pulp exposures were capped with calcium hydroxide and resin composite (tetric n-ceram and its universal bond) as final restoration on one side of the mouth and on the other side of the mouth the pulp was capped with the same adhesive and resin composite restoration but containing bioactive glass. Materials were applied according to the manufacturer's instructions as mentioned above ${ }^{(18)}$.

\section{Preparations for histological study:}

After the assigned periods of time, animals were re-anesthetized with the former protocol. Then the animals were scarified by injection of overdose of $10 \%$ thiopental sodium at fourteen and sixty days postoperatively ${ }^{(15)}$. The maxilla and the mandible were removed surgically and sectioned into two halves at the midline. The jaws with the teeth were directly fixed in formaldehyde solution $10 \%$. The apical third of the root was removed in order to facilitate formalin penetration and fixation.

After teeth were fixed for two weeks, the specimens were demineralized in Morse's solution (50\% formic acid $+20 \%$ sodium citrate) for two months. After complete decalcification is verified by punching, specimens were dehydrated in ascending concentration of ethanol. Finally, the teeth were embedded in paraffin and serially sectioned in a buccolingual directions coming through the pulp exposure site using a microtome and five $\mu \mathrm{m}$ sections were obtained. All sections were stained with Mayer's hematoxylin-eosin stain after collecting them on glass slides. The histopathological features were evaluated using light microscopy (leica microscpe) which include a digital camera mounted on it. All images were captured by the digital camera (BX 100) and transferred to the computer system by leica software (leica queen) ${ }^{(19)}$. Each section was graded according to the criteria listed in table (1) ${ }^{(20)}$. 
Table (1): Scoring system for hard tissue formation, Pulp tissue disorganization and inflammatory cell infiltrate.

\begin{tabular}{|c|c|}
\hline Grade & Characterization \\
\hline \multicolumn{2}{|c|}{ Scoring system for Inflammatory cell infiltrate } \\
\hline $\mathbf{0}$ & $\begin{array}{l}\text { No or few inflammatory cells scattered in the } \\
\text { pulp. }\end{array}$ \\
\hline 1 & $\begin{array}{l}\text { A small number of inflammatory cells gathered at } \\
\text { the exposure area. }\end{array}$ \\
\hline 2 & $\begin{array}{l}\text { A number of inflammatory cells infiltrated in the } \\
\text { coronal pulp. }\end{array}$ \\
\hline 3 & Necrosis or abscess formation \\
\hline \multicolumn{2}{|c|}{ Scoring system for Pulp tissue disorganization } \\
\hline $\mathbf{0}$ & Normal pulp tissue morphology \\
\hline 1 & $\begin{array}{l}\text { Discrete pulp disorganization close to the pulp } \\
\text { exposure site but normal central pulp }\end{array}$ \\
\hline 2 & $\begin{array}{l}\text { More widely spread disorganization of the pulp } \\
\text { tissue morphology }\end{array}$ \\
\hline 3 & Total pulp tissue disorganization or pulp necrosis \\
\hline \multicolumn{2}{|c|}{ Scoring system for Hard tissue formation } \\
\hline $\mathbf{0}$ & No hard tissue formation \\
\hline 1 & $\begin{array}{l}\text { Limited hard tissue deposition below or around } \\
\text { the exposure }\end{array}$ \\
\hline 2 & $\begin{array}{l}\text { Hard tissue deposition below or around the } \\
\text { exposure extending to more than half but not } \\
\text { completely closing the exposure site. }\end{array}$ \\
\hline 3 & $\begin{array}{l}\text { Hard tissue formed across the exposure site } \\
\text { completely }\end{array}$ \\
\hline
\end{tabular}

\section{Statistical analysis:}

In the animal experimental model, the data were statistically analyzed by the cross-tabulation analysis (non-parametric analysis) to analyze the association between the experimental periods (14 and 60 days) and dependent variables of the inflammatory cell infiltration, the pulp tissue disorganization and the dentin bridge formation.

Data was represented as mean \pm standard error of mean (SEM), Since the data were non parametric. In order to compute the increase or decrease in the percentage of change and/or difference for the studied parameters of a desired dependent variable (treated variable) in relation to another dependent variable (e.g. control or base line variable) as a result to an effect of an independent variable (e.g. drug dose and or time), the following formula was applied:

$\%$ of change $=($ treated variable $/$ control or base line variable -1$) * 100$.

The descriptive and inferential statistics were done by the aid of IBM Statistical Package for the Social Sciences (SPSS) software version 26.

\section{RESULTS}

Effect of treatment protocol regardless the effect of the time:

\section{Inflammatory cell infiltrate:}

According to Mann-Whitney U test analyses after fourteen days of treatment with the light-cured $\mathrm{Ca}(\mathrm{OH})_{2}(\mathrm{P} 1)$ or resin composite and its adhesive system containing bioactive glass (P2), there was no significant difference for the inflammatory cell infiltrate with a percentage of change $(-45.5 \%)$ (Table 2, Fig. 2). On bases of the frequency levels, the severe percentage of the inflammatory cell infiltrate was observed with a low percentage $(10 \%)$ in the resin composite and its adhesive system containing bioactive glass group whereas those treated with the light-cured $\mathrm{Ca}(\mathrm{OH})_{2}$ was quantified by three folds (30\%) as shown in (Table 3 and Fig. 3). After 60 days, the mean value of inflammatory cell infiltrate, of the resin composite and its adhesive system containing bioactive glass group was significantly less than those light-cured calcium hydroxide with a percentage of change (-58.3\%) as shown in (Table 3 and Fig. 4).

Additionally, the severe inflamed cells were not observed in dogs exposed to resin composite and its adhesive containing bioactive glass after 60 days $(0.00 \%)$ whereas these cells were $10 \%$ in lightcured $\mathrm{Ca}(\mathrm{OH})_{2}$ group (Table 3 and Fig. 5). 
Table (2): Frequencies of the histopathological scores of the inflammatory cell infiltrate, in teeth of mongrel male dog, after 14 days of treatment with (P1) or (P2) regardless of the time.

\begin{tabular}{|c|c|c|c|c|}
\hline \multicolumn{5}{|c|}{ Inflammatory cell infiltrate } \\
\hline $\begin{array}{l}\text { Frequencies of } \\
\text { histopathological scores }\end{array}$ & \multicolumn{2}{|c|}{$\begin{array}{l}\text { Light-cured } \mathrm{Ca}(\mathrm{OH})_{2} \\
(\mathrm{P1})\end{array}$} & \multicolumn{2}{|c|}{$\begin{array}{l}\text { Resin composite and its adhesive system containing bioactive glass } \\
\text { (P2) }\end{array}$} \\
\hline Normal & 0 & $(0.00 \%)$ & 0 & $(0.00 \%)$ \\
\hline Mild & 1 & $(10 \%)$ & 4 & $(40 \%)$ \\
\hline Moderate & 6 & $(60 \%)$ & 5 & $(50 \%)$ \\
\hline Severe & 3 & $(30 \%)$ & 1 & $(10 \%)$ \\
\hline$\overline{\mathrm{X}} \pm \mathrm{SEM}{ }^{\bullet}$ & \multicolumn{2}{|c|}{$2.2 \pm 0.200$} & \multicolumn{2}{|c|}{$1.2 \pm 0.327^{\mathrm{ns}}$} \\
\hline \multicolumn{3}{|c|}{ Percentage of change } & \multicolumn{2}{|c|}{$(-45.5 \%)$} \\
\hline
\end{tabular}

1: Average of frequencies \pm SEM.

ns: No significant difference in comparison with dogs treated with the light-cured $\mathrm{Ca}(\mathrm{OH})_{2}$.

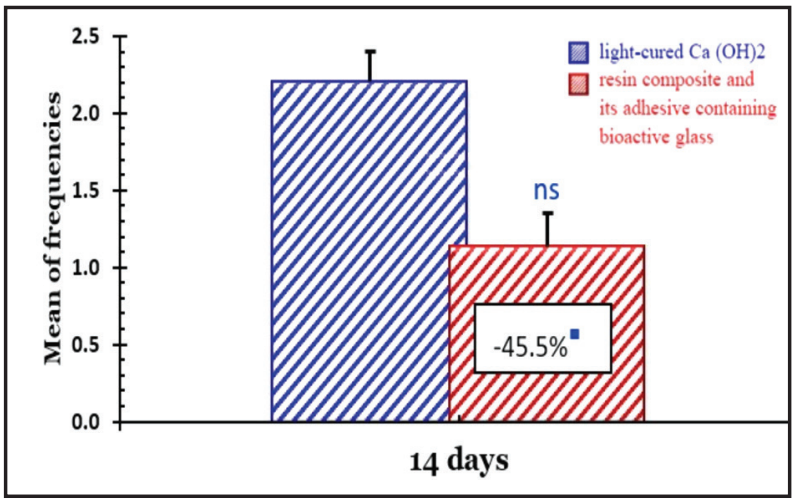

Figure (2) Bar chart representing the mean of histopathological scores of the assigned the inflammatory cell infiltrate, in teeth of the male mongrel dogs, after 14 days of treatment with $(\mathrm{P} 1)$ or $(\mathrm{P} 2)$. Each bar is a mean \pm SEM. ns: No significant difference $\left(\mathrm{P}^{3} 0.05\right)$.

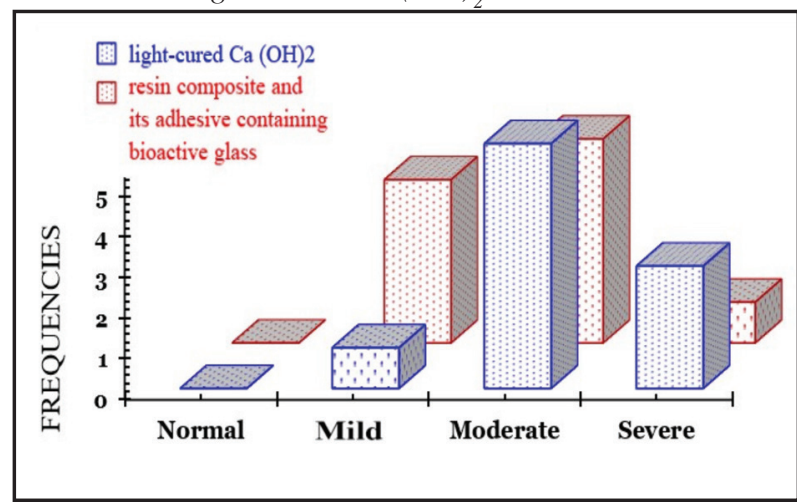

Figure (3) 3-D column representing frequencies of the histopathological scores of the inflammatory cell infiltrate, in teeth of the male mongrel dogs, after 14 days of treatment with $(\mathrm{P} 1)$ or $(\mathrm{P} 2)$.

Table (3): Frequencies of the histopathological scores of the inflammatory cell infiltrate, after 60 days of treatment with $(P 1)$ or $(P 2)$ regardless of the time.

\begin{tabular}{ccccc}
\hline \multicolumn{5}{c}{ Inflammatory cell infiltrate } \\
\hline $\begin{array}{c}\text { Frequencies of } \\
\text { histopathological scores }\end{array}$ & $\begin{array}{c}\text { Light-cured Ca }(\mathbf{O H})_{2} \\
(\mathbf{P 1})\end{array}$ & $\begin{array}{c}\text { Resin composite and its adhesive system containing bioactive glass } \\
(\mathbf{P 2})\end{array}$ \\
\hline Normal & 3 & $(30 \%)$ & 6 & $(60 \%)$ \\
Mild & 3 & $(30 \%)$ & 3 & $(30 \%)$ \\
Moderate & 3 & $(30 \%)$ & 1 & $(10 \%)$ \\
Severe & 1 & $(10 \%)$ & 0 & $0.3 \pm 0.224 *$ \\
\hline $\mathbf{X} \pm$ SEM & $1.2 \pm 0.327$ & & $(-58.3 \%)$ \\
\hline Percentage of change & & & \\
\hline
\end{tabular}

1: Average of frequencies \pm SEM.

*: Significant difference in comparison with dogs treated with the light-cured $\mathrm{Ca}(\mathrm{OH})_{2}$ 


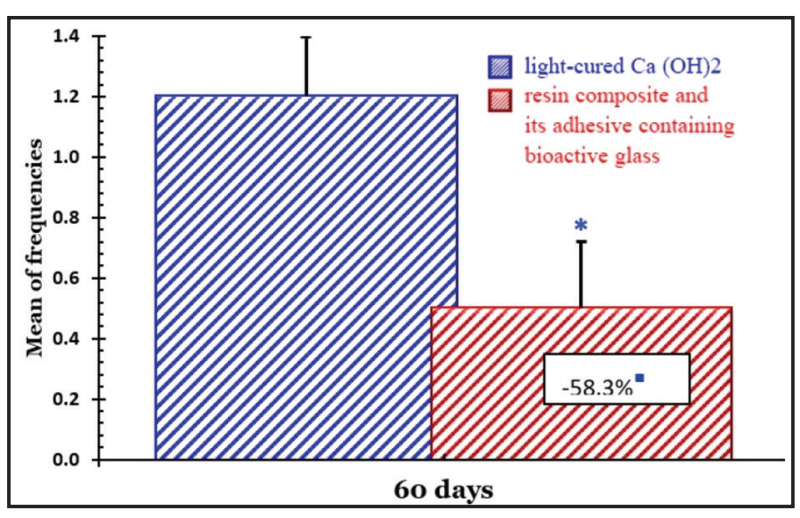

Figure (4) Bar chart representing the mean of histopathological scores of inflammatory cell infiltrate, after 60 days of treatment $(\mathrm{P} 1)$ or $(\mathrm{P} 2)$. Each bar is a mean \pm SEM. *: Significant difference $(\mathrm{P}<0.05)$.

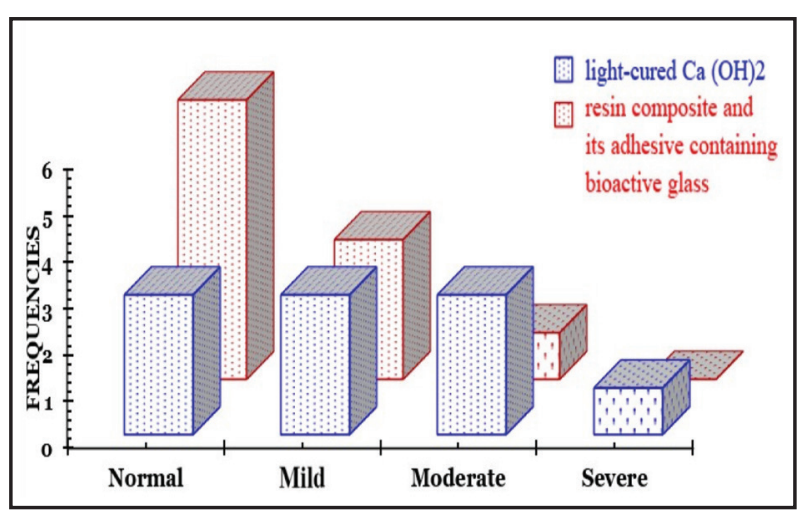

Figure (5) 3-D column representing frequencies of the histopathological scores of inflammatory cell infiltrate, after 60 days of treatment with (P1) or (P2).

Figure 4:

\section{Pulp tissue disorganization:}

According to the Mann-Whitney test, after 14 days of exposure to the light-cured $\mathrm{Ca}(\mathrm{OH})_{2}$ and the resin composite with its adhesive system containing bioactive glass, there was a significant difference between the assigned mean of frequencies (scores) of pulp tissue disorganization (Table 4, Fig. 6). In relation to the light cure $\mathrm{Ca}(\mathrm{OH})_{2}$, the percentage of change for the pulp tissues disorganization, in tooth treated with resin composite with its adhesive system containing bioactive glass was markedly reduced by $63.6 \%$ (Table 4, Fig. 6).
The frequencies of severe pulp disorganization in samples treated with resin composite and its adhesive system containing bioactive glass were obviously reduced three folds with a ratio (1:3) when compared with those exposed to the lightcured $\mathrm{Ca}(\mathrm{OH})_{2}$ (Table 4, Fig. 7). As shown the results in (Table 5) the pulp tissues disorganization was reduced, as affirmed by Mann-Whitney U test, as a response to the resin composite and its adhesive system containing bioactive glass and became significantly less than those in teeth treated with the light-cured $\mathrm{Ca}(\mathrm{OH})_{2}, 60$ days post-treatment.

In addition, the computed average of frequencies percentage scores of the pulp tissues disorganization of change, in the resin composite and its adhesive containing bioactive glass, exhibited a severe marked depletion $(-68.8 \%)$ in relation to the lightcured $\mathrm{Ca}(\mathrm{OH})_{2}$ group (Fig. 8). From the frequencies view, the severe type of pulp tissues disorganization in samples treated with the resin composite and its adhesive containing bioactive glass were severely depleted and completely disappeared after 60 days which represented by $0.00 \%$ in comparison with those exposed to the light-cured $\mathrm{Ca}(\mathrm{OH}) 2$ and estimated by $20 \%$ (Table 5, Fig. 9).

Table (4) Frequencies of the histopathological scores of the pulp tissues disorganization, after 14 days of treatment $(P 1)$ or $(P 2)$ regardless the effect of time.

\section{Pulp tissue disorganization}

\begin{tabular}{ccccc}
\hline $\begin{array}{c}\text { Frequencies of } \\
\text { histopathological } \\
\text { scores }\end{array}$ & $\begin{array}{c}\text { Light-cured } \\
\mathbf{C a}(\mathbf{O H})_{2}\end{array}$ & $\begin{array}{c}\text { Resin composite } \\
\text { and its adhesive } \\
\text { system containing } \\
\text { bioactive glass }\end{array}$ \\
\hline Normal & 0 & $(0.00 \%)$ & 0 & $(0.00 \%)$ \\
Mild & 1 & $(10 \%)$ & 7 & $(70 \%)$ \\
Moderate & 6 & $(60 \%)$ & 2 & $(20 \%)$ \\
Severe & 3 & $(30 \%)$ & 1 & $(10 \%)$ \\
\hline$\overline{\mathbf{X}}_{ \pm}$SEM & $2.2 \pm 0.200$ & \multicolumn{2}{c}{$1.4 \pm 0.221 \%$} \\
\hline Percentage of change & \multicolumn{2}{c}{$(-63.6 \%)$} \\
\hline
\end{tabular}

1. Average of frequencies \pm SEM.

*: Significant difference in comparison with dogs treated with the light-cured $\mathrm{Ca}(\mathrm{OH})_{2}$ group.

- Percentage of change in relation to the mean of the light-cured $\mathrm{Ca}(\mathrm{OH})_{2}$. 


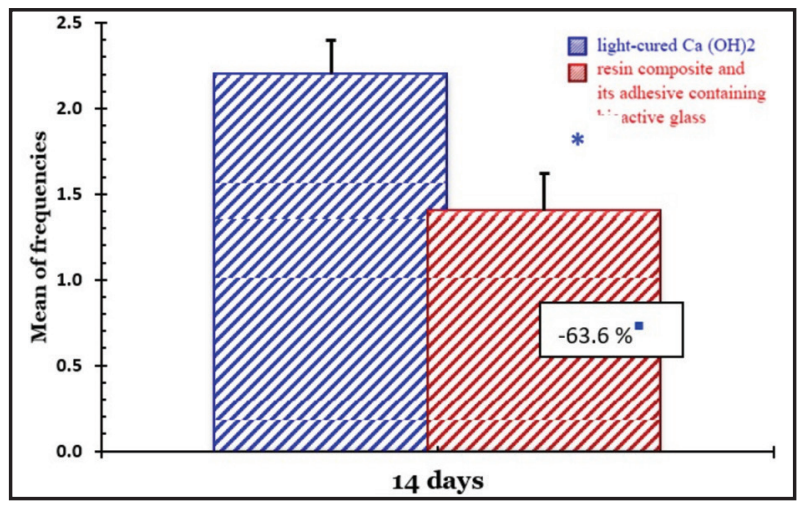

Figure (6) Bar chart representing the mean of histopathological scores of the assigned pulp tissues disorganization, after fourteen days of treatment with (P1) or (P2). Each bar is a mean \pm SEM. *: Significant difference $(\mathrm{P}<0.05)$.": Percentage of change.

Table (5) Frequencies of the histopathological scores of the pulp tissues disorganization, after 60 days of treatment with $(P 1)$ or $(P 2)$ regardless the effect of time.

\begin{tabular}{ccccc}
\hline \multicolumn{5}{c}{ Pulp tissue disorganization } \\
\hline $\begin{array}{c}\text { Frequencies of } \\
\text { histopathological } \\
\text { scores }\end{array}$ & $\begin{array}{c}\text { Light-cured } \\
\text { Ca }(\mathbf{O H})_{2}\end{array}$ & $\begin{array}{c}\text { Resin composite and } \\
\text { its adhesive system } \\
\text { containing bioactive glass }\end{array}$ \\
\hline Normal & 2 & $(20 \%)$ & 6 & $(60 \%)$ \\
Mild & 2 & $(20 \%)$ & 3 & $(30 \%)$ \\
Moderate & 4 & $(40 \%)$ & 1 & $(10 \%)$ \\
Severe & 2 & $(20 \%)$ & 0 & $(0.00 \%)$ \\
\hline $\bar{X} \pm$ SEM & $1.6 \pm 0.340$ & & $0.5 \pm 0.224 *$ \\
\hline Percentage of change & & $(-68.8 \%)$ \\
\hline
\end{tabular}

-: Average of frequencies \pm SEM.

*: Significant difference in comparison with the lightcured $\mathrm{Ca}(\mathrm{OH})_{2}$.

$\because$ Percentage of change.

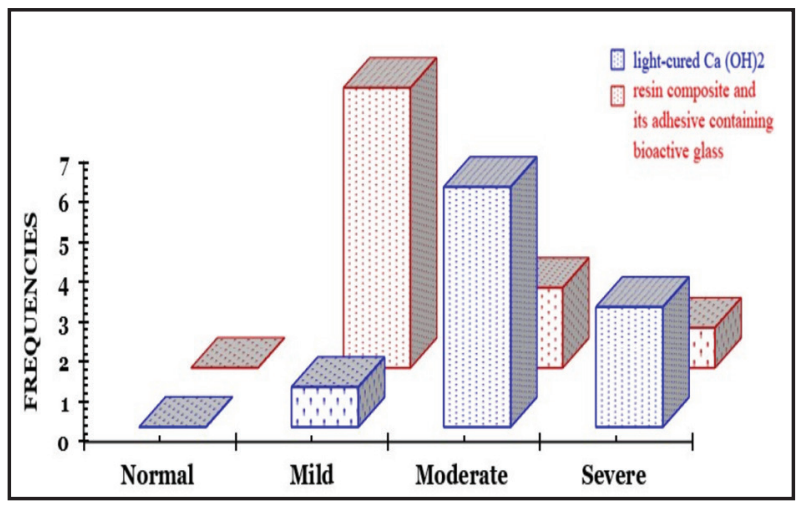

Figure (7) 3-D column representing frequencies of the histopathological scores of the pulp tissues disorganization, after fourteen days of treatment with (P1) or (P2).

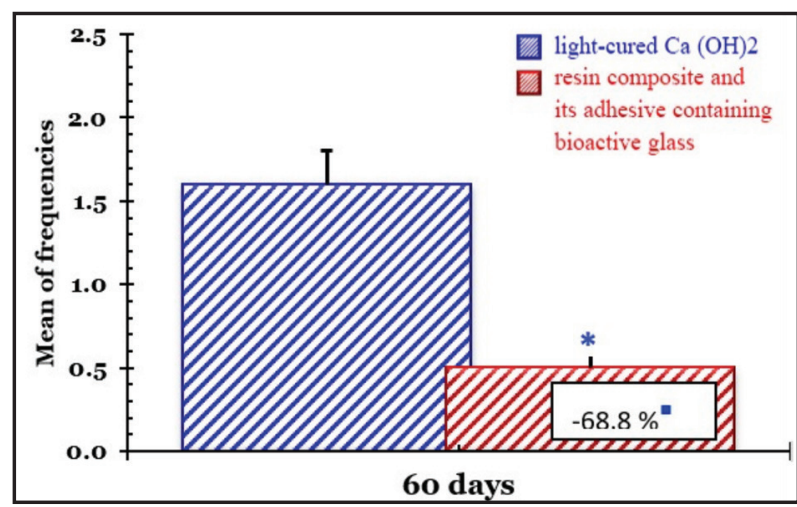

Figure (8) Bar chart representing the mean of histopathological scores of the assigned pulp tissues disorganization, after 60 days of treatment with (P1) or (P2). Each bar is a mean \pm SEM. *: Significant difference $(\mathrm{P}<0.05)$. ": Percentage of change.

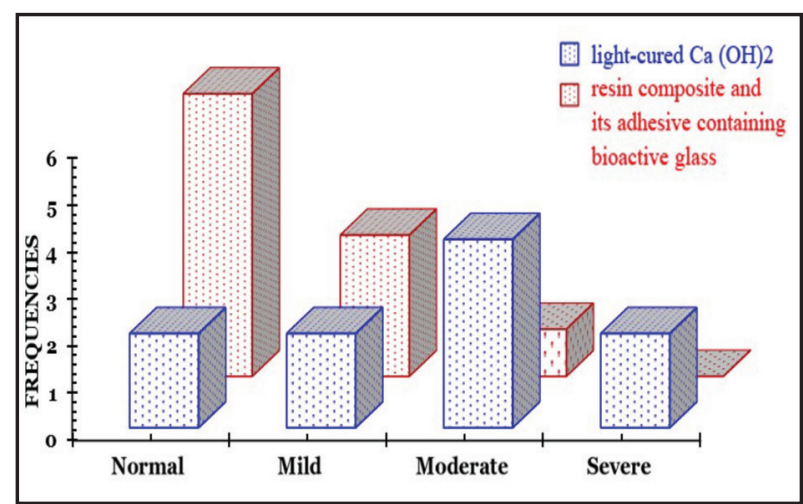

Figure (9) 3-D column representing frequencies of the histopathological scores of the pulp tissues disorganization, after 60 days of treatment with (P1) or (P2). 


\section{Hard tissue formation:}

As confirmed by Mann-Whitney test, after 14 days of application of both materials, there was no significant difference between the assigned mean of frequency (scores) of hard tissue formation. The percentage of change was $400 \%$ (Table 6, Fig. 10). A very limited tissue deposition for each of light-cured $\mathrm{Ca}(\mathrm{OH})_{2}$ or the resin composite and its adhesive system containing bioactive glass was observed, at this period (Table 6, Fig. 11). While the average of hard tissue formation of light-cured $\mathrm{Ca}(\mathrm{OH})_{2}$ group showed a significant decrease when compared with the resin composite and its adhesive system containing bioactive glass group after 60 days. The percentage of change was $60 \%$ in relation to the light-cured $\mathrm{Ca}(\mathrm{OH})_{2}$ group (Table 7. Fig. 12) The complete hard tissue formation, in resin composite and its adhesive system containing bioactive glass group (50\%) that was greater five folds than those treated with the light-cured $\mathrm{Ca}(\mathrm{OH}) 2(10 \%)$. (Table 7, Fig.13)

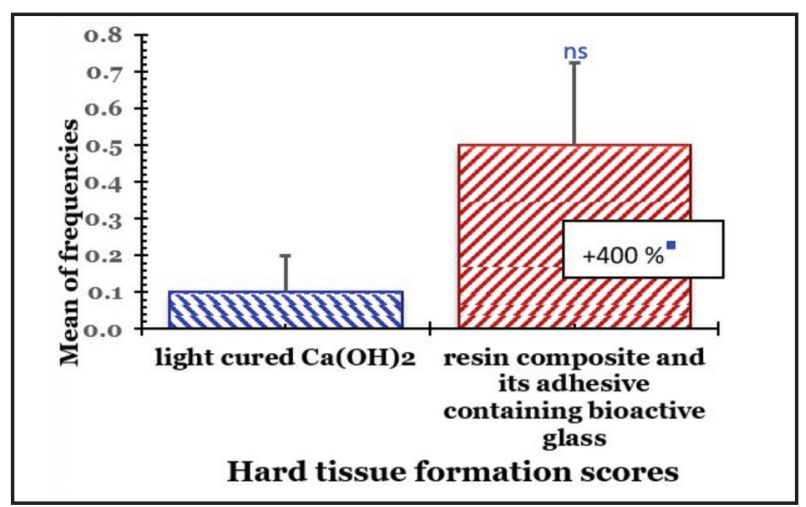

Figure (10) Bar chart representing the mean of histopathological frequencies (scores) of the assigned hard tissue formation, after 14 days of treatment (P1) or (P2). Each bar is a mean of \pm SEM. ns: No significant difference $\left(\mathrm{P}^{3} 0.05\right)$. ": Percentage of change in relation to lightcured $\mathrm{Ca}(\mathrm{OH})_{2}$ group.
Table (6) Frequencies of the histopathological scores of the hard tissue formation in the dentin bridge after 14 days of treatment with (P1) or (P2) regardless the effect of time.

\begin{tabular}{|c|c|c|c|c|}
\hline \multicolumn{5}{|c|}{ Hard tissue formation } \\
\hline \multirow{2}{*}{$\begin{array}{c}\begin{array}{c}\text { Frequencies of } \\
\text { histopathological } \\
\text { scores }\end{array} \\
\text { No HT }\end{array}$} & \multicolumn{2}{|c|}{$\begin{array}{l}\text { Light-cured } \\
\text { Ca }(\mathrm{OH})_{2} \\
(\mathrm{P} 1)\end{array}$} & \multicolumn{2}{|c|}{$\begin{array}{c}\text { Resin composite and } \\
\text { its adhesive system } \\
\text { containing bioactive glass } \\
\text { (P2) }\end{array}$} \\
\hline & 9 & $(90 \%)$ & 6 & $(60 \%)$ \\
\hline Initial HT & 1 & $(10 \%)$ & 3 & $(30 \%)$ \\
\hline Partial HT & 0 & $(0.00 \%)$ & 1 & $(10 \%)$ \\
\hline Complete HT & 0 & $(0.00 \%)$ & 0 & $(0.00 \%)$ \\
\hline$\overline{\mathbf{X}} \pm$ SEM 1 & \multicolumn{2}{|c|}{$0.1 \pm 0.100$} & \multicolumn{2}{|c|}{$0.5 \pm 0.224^{(\mathrm{ns})}$} \\
\hline \multicolumn{3}{|c|}{ Percentage of change " } & & \\
\hline \multicolumn{5}{|c|}{$\begin{array}{l}\text { HT: Hard tissue. }{ }^{1} \text { : Average of ten frequencies } \pm \text { SEM. } \\
\text { (ns): Insignificant difference }\left(\mathrm{P}^{3} \mathrm{O} .05\right) \text { in comparison } \\
\text { with the mean of frequency the light-cured } \mathrm{Ca}(\mathrm{OH})_{2} \\
\text { group. ": Percentage of change in relation to dogs } \\
\text { treated with the light-cured } \mathrm{Ca}(\mathrm{OH})_{2}\end{array}$} \\
\hline
\end{tabular}

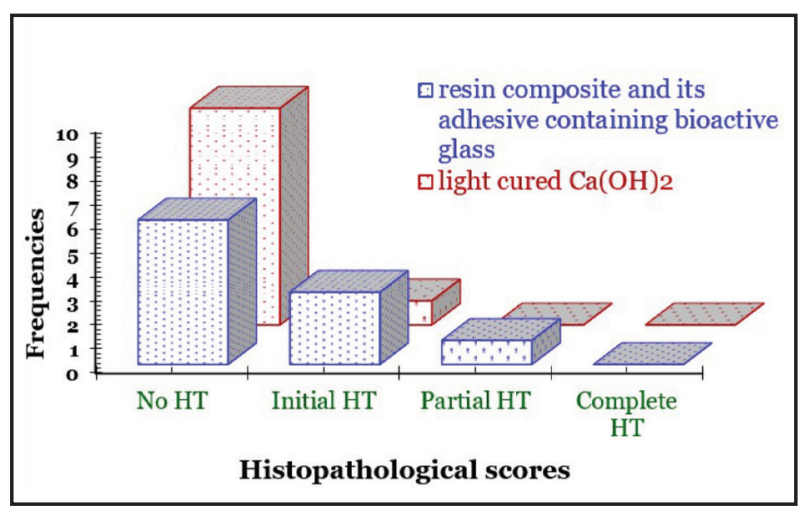

Figure (11) 3-D column representing frequencies of the histopathological scores at various stages during the hard tissue (HT) formation in the dentin bridge, in teeth of the male mongrel dogs, after 14 days of treatment (P1) or (P2). 
Table (7): Frequencies of the histopathological scores of the hard tissue formation in the dentin bridge after 60 days of treatment with $(P 1)$ or $(P 2)$ regardless the effect of time.

\begin{tabular}{|c|c|c|c|c|}
\hline \multicolumn{5}{|c|}{ Hard tissue formation } \\
\hline $\begin{array}{c}\text { Frequencies of } \\
\text { histopathological scores }\end{array}$ & \multicolumn{2}{|c|}{ Light-cured $\mathrm{Ca}(\mathrm{OH})_{2}$} & \multicolumn{2}{|c|}{$\begin{array}{l}\text { Resin composite and its adhesive system } \\
\text { containing bioactive glass }\end{array}$} \\
\hline No HT & 2 & $(20 \%)$ & 0 & $(0.00 \%)$ \\
\hline Initial HT & 2 & $(20 \%)$ & 1 & $(10 \%)$ \\
\hline Partial HT & 5 & $(50 \%)$ & 4 & $(40 \%)$ \\
\hline Complete HT & 1 & $(10 \%)$ & 5 & $(50 \%)$ \\
\hline$\overline{\mathbf{X}} \pm \mathrm{SEM}{ }^{\circ}$ & \multicolumn{2}{|c|}{$1.5 \pm 0.307$} & \multicolumn{2}{|c|}{$2.4 \pm 0.049 *$} \\
\hline \multicolumn{3}{|c|}{ Percentage of change " } & \multicolumn{2}{|c|}{$(+60 \%)$} \\
\hline
\end{tabular}

HT: Hard tissue.

-: Average of frequencies \pm SEM.

*: Significant difference $\left(P^{3} 0.05\right)$ in comparison with the mean of frequency in the light-cured $\mathrm{Ca}(\mathrm{OH})_{2}$ group.": Percentage of change in relation to the light-cured $\mathrm{Ca}(\mathrm{OH})_{2}$ group.

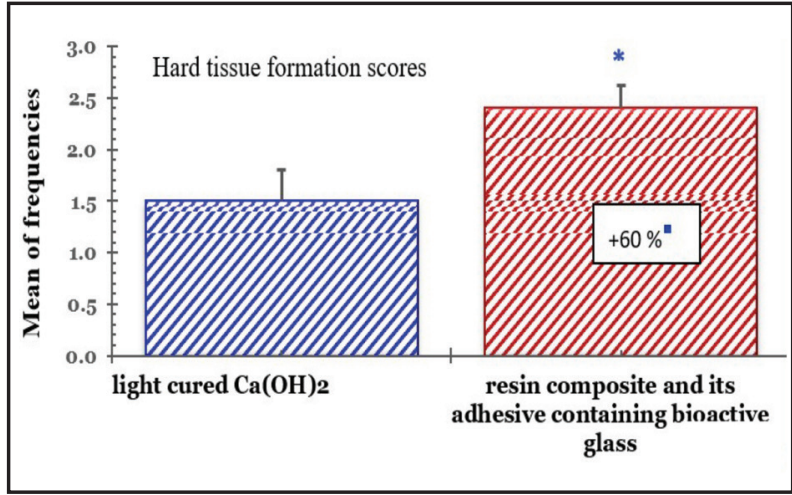

Figure (12) Bar chart representing the mean of histopathological frequencies (scores) of the assigned hard tissue formation, after sixty days of treatment with the lightcured $\mathrm{Ca}(\mathrm{OH})$, and the resin composite and its adhesive containing bioactive glass. Each bar is a mean of \pm SEM. *: Significant difference $(\mathrm{P}<0.05)$. ": Percentage of change in relation to light-cured $\mathrm{Ca}(\mathrm{OH})_{2}$ group.

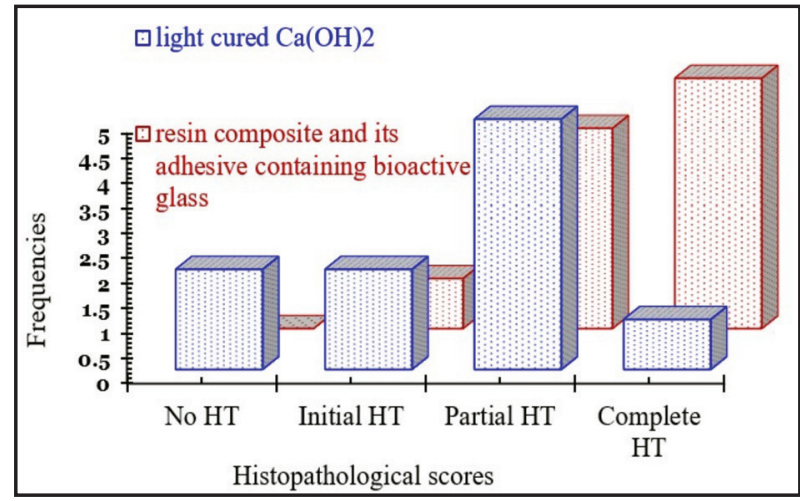

Figure (13) 3-D column representing frequencies of the histopathological scores at various stages during the hard tissue (HT) formation in the dentin bridge, after 60 days of treatment with the light-cured $\mathrm{Ca}(\mathrm{OH})_{2}$ or the resin composite and its adhesive system containing bioactive glass.

\section{Histopathological results:}

\section{i. Light cured Calcium hydroxide experimental group (P1):}

\section{a. After 14 days (T1):}

By examination of the pulp tissue after capping with light cured Calcium hydroxide, away from the exposure site showed dilated blood vessels, vacuolated cytoplasm and loss of odontoblastic architecture (Fig. 14-a). No dentin bridge was formed in most of the specimens at this time. (Fig. 15-a). 


\section{b. After 60 days (T2):}

By examination the pulp tissue of this group after 60 days, adjacent to the exposure site after capping with light cured Calcium hydroxide showed, few dilated blood vessels and few inflammatory cells were observed in some cases, the remaining pulp tissue showed dense fibrous connective tissue (Fig. 14-c). In most of the specimens, the pulp revealed separated odontoblastic layer, (Fig. 15c). Incomplete dentin bridge was formed in most of the specimens, irregular secondary dentin and osteodentin formation were observed in some cases at this time. (Fig. 15-c).

\section{ii. Resin composite and its adhesive containing bioactive glass experimental group (P2):}

\section{a. After 14 days (T1):}

By examination of the pulp tissue of this group, away from the exposure site after capping with resin composite and its adhesive containing bioactive glass, some of the specimens show numerous congested blood vessels and normal architecture of odontoblastic layer (Fig. 14-b). Fibrous tissue formation was observed in the exposure site which indicates initial dentin bridge formation in most of the specimens. Irregular secondary dentin also was observed under the exposure site at this time. (Fig. 15-b).

\section{b. After 60 days (T2):}

By examination of this group after capping with resin composite and its adhesive containing bioactive glass, diffuse pulp calcification and hyalinization were observed (Fig. 14-d). Complete dentin bridge formation was observed in most of the specimens which may be atubular dentin (Fig. 15-d), in addition to incomplete dentin bridge in the form of tubular dentin was found in few cases at this time (Fig. 14-d).

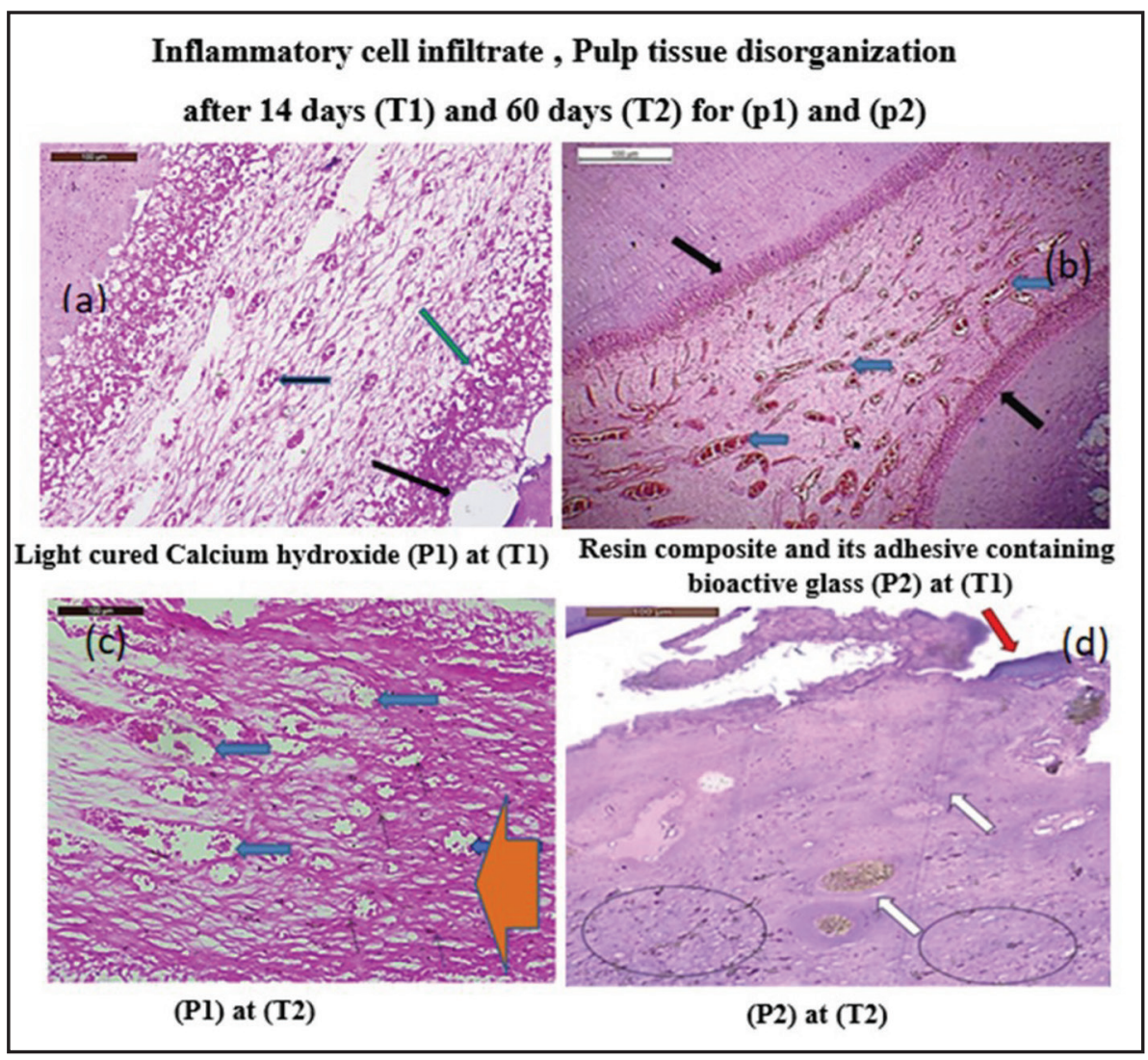

Figure (14) (a,b,c,d):

Photomicrographs of Light cured Calcium hydroxide group and Resin composite and its adhesive containing bioactive glass group showing inflammatory cell infiltration and pulp tissue disorganization after 14 and 60 days where:

a: Dilated blood vessels (blue arrow) detachment and loss of odontoblastic architecture (black arrow) with vacuolation of the cytoplasm (green arrow) (H\&E, mag. x200).

b: Numerous congested blood vessels (blue arrow) and normal odontoblastic layer (black arrow). (H\&E, mag. x 400).

c: Dilated blood vessels (blue arrows), few inflammatory cells (black arrow) and formation of dense fibrous connective tissue (orange arrow) (H\&E, mag. $x$ 200).

d: Hyaline degeneration (white arrow), diffuse calcification (oval shape) and partial tubular dentin bridge (red arrow). (H\&E, mag. x 400). 


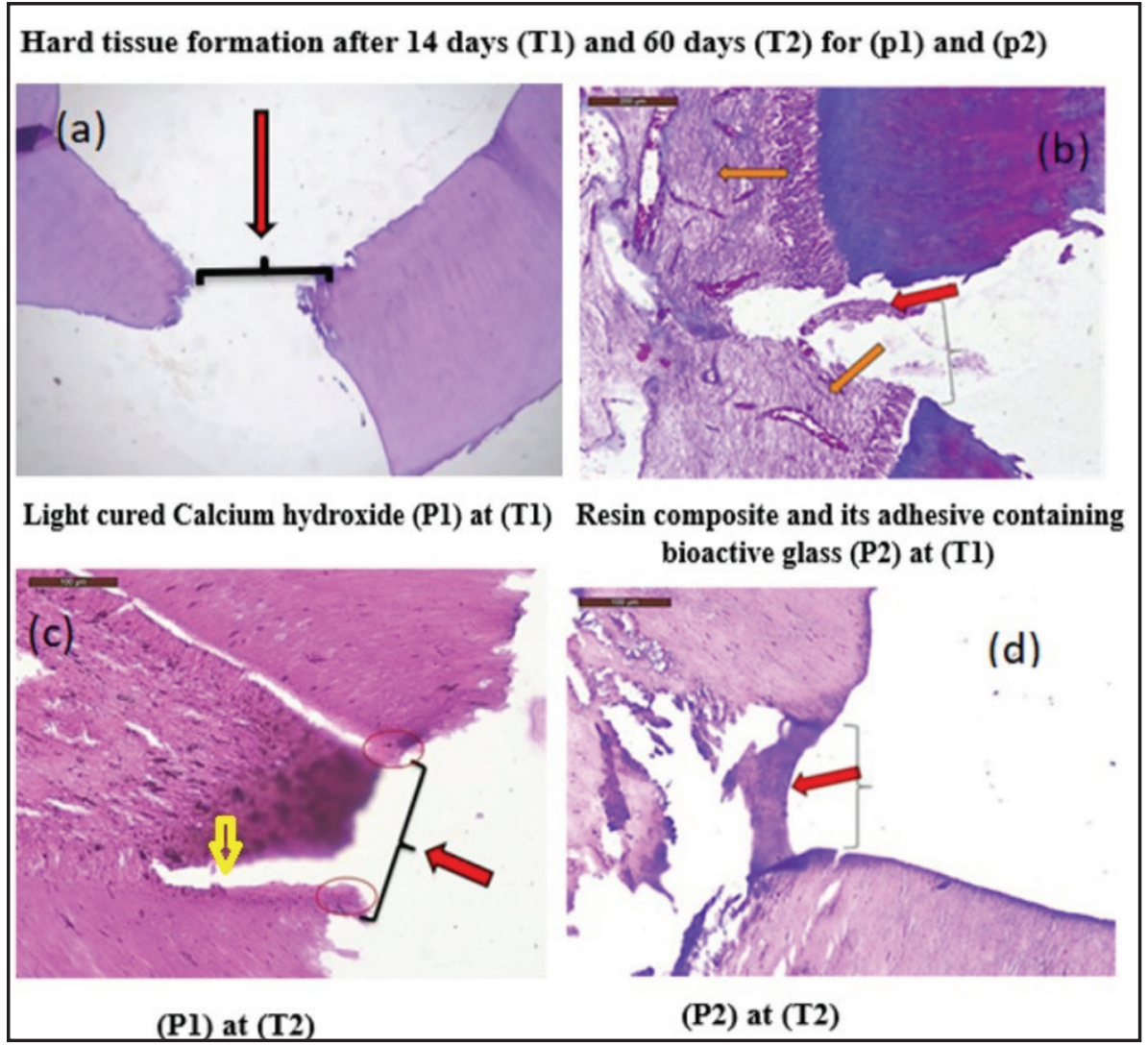

Figure (15) (a, b, c, d): Photomicrographs of Light cured Calcium hydroxide group and Resin composite and its adhesive containing bioactive glass group showing hard tissue formation after 14 and 60 days where:

a: No dentin bridge (red arrow) (H\& E, mag. x 40).

b: Fibrous tissue under the exposure site (red arrow) and irregular secondary dentin (orange arrows) (H\&E, mag. x 100).

c: Separation of odontoblastic layer under the exposure site (yellow arrow), beginning of calcification of new dentin bridge (red arrow), irregular secondary dentin and osteodentin (red circle) (H\&E, mag. x 200).

d: Thick well calcified dentin bridge (atubular dentin) under the prepared cavity (red arrow) (H\&E, mag. x 200).

\section{DISCUSSION}

Direct pulp capping (DPC) is a treatment protocol for reversible pulp injuries which aims to maintain function and vitality of the pulp. Vital and functional dentin is needed beneath the injured site for long term success of DPC ${ }^{(15)}$. Pulp capping using calcium hydroxide-based agent has been a gold standard therapy for years. However, longterm studies have shown results to be variable and unpredictable ${ }^{(21)}$. Therefore, a biocompatible, bioactive agent that rapidly induces reparative dentin formation possessing a good quality is required to improve the clinical success rate of vital pulp therapy ${ }^{(22)}$.

Bioactive glass (BG) has found its niche in dentistry, results of an in vivo study on implantation of bioactive glasses showed also that these materials produce no toxicity, no inflammation, and no foreign-body response ${ }^{(23)}$. Besides that its antimicrobial activity against intraoral bacteria has been confirmed by many studies ${ }^{(10,23,24)}$. Another proposal for different potential sources of $\mathrm{Ca}^{-2}$ and $\left(\mathrm{Po}_{4}\right)^{-3}$ ions for biomimetic remineralization were bioactive glass and resin composites or adhesives containing bioactive glass ${ }^{(23)}$.

The bioactivity of these materials were found to enhance the life time and strength of the hybrid layer by increasing the local $\mathrm{pH}$ leading to inhibiting MMPS activity and by precipitation hydroxyapatite within the demineralized collagen network and so minimizing the nanoleakage and increasing the protection of the hybrid layer from hydrolytic degradation ${ }^{(25)}$. Hence, this study was conducted to evaluate the effect of application of bioactive glass (BG) which incorporated in resin composite and its adhesive system (P2) as direct pulp capping agent through investigating the pulpal tissue reaction of the samples comparing this effect with light cured calcium hydroxide (P1). 
Bioactive glass nanoparticles were weighed and added to the adhesive with a ratio of $10 \%$ by weight in the current study, as it was proved that $10 \%$ added filler yielded higher strength than $20 \%{ }^{(25)}$. Bioactive glass nanoparticles were incorporated in the resin composite with a ratio of $5 \%$ in the current study. Bioactive glass on a nanoscale was used as it was shown that bioactive glass nanoparticles (BGNs) have a greater surface area, allowing rapid surface interactions and reactions with biological components, better biological and mechanical properties $^{(26)}$. Moreover, the antibacterial effect of bioactive glasses could be greatly enhanced by lowering their particle size ${ }^{(7)}$. It was synthesized by new technology which is the sol-gel method, this method can solve agglomeration problems and control the size, texture and morphology of bioactive glass ${ }^{(27)}$.

Dogs were recruited as experimental animals due to the fact that they have induction mechanism and dentin formation similar to human teeth. Dogs are considered as good fit for experimental study since their pulp tissue is comparable to that of humans in spite of the fact that the reparative dentinogenesis rate may be different ${ }^{(16)}$. Exposed pulps were directly capped with both tested materials. After pulp capping, resin composite restoration was used to provide immediate sealing as it has good sealing properties, due to recent improvements in adhesive bonding with cavity walls ${ }^{(11,28,29)}$. As there is a suggestion which states that the seal's provision opposing the entrance of bacteria could possibly be the highest crucial reason among a successful vital pulp therapy ${ }^{(20)}$.

As only histological investigation can give objective data for the real status of the pulp ${ }^{(29)}$. So, histopathologic examination was performed at 2 weeks (14 days) and eight weeks (60 days). The two weeks (14 days) time interval was selected on the basis of the studies which showed that, at least two weeks are required to initiate the differentiation of odontoblasts like cells and hard tissue formation ${ }^{(30)}$. Sixty days time interval was used to analyze pulp response finally to find whether there is any difference in response compared with 14 days ${ }^{(18,31)}$.

In judging the efficacy of a material as a pulpcapping agent, it is important to determine the presence or absence of inflammation (type and severity), necrosis and resorption of dentinal walls (pulp condition) in addition to calcified bridge formation $^{(32)}$. So the scoring system selected in the present study included inflammatory cells infiltration, pulp tissue disorganization and hard tissue formation ${ }^{(31)}$.

Results of this study indicated that after 14 days (T1), although resin composite and its adhesive containing bioactive glass had better outcome than light cured calcium hydroxide concerning inflammatory cells infiltration, pulp disorganization and hard tissue formation, but there was no statistically significant difference between the two experimental groups in terms of Inflammatory cell infiltrate and hard tissue formation.

For inflammatory cells infiltration and pulp tissue disorganization results using light cured calcium hydroxide at 14 days, $60 \%$ showed number of inflammatory cells infiltrated in the coronal pulp, $60 \%$ showed wide spread pulp disorganization but not completely closing the exposure site, while $30 \%$ showed total pulp tissue disorganization. These results were correlated to the histopathological examination which revealed that adjacent to the exposure site, severe inflammatory cells infiltration was noticed and the odontoblastic layer was discontinuous (14-a).

In some specimens the pulp tissue away from the exposure site showed moderate inflammatory cells infiltration, dilated blood vessels, vacuolated cytoplasm and loss of odontoblastic architecture (14-a), while $30 \%$ showed necrosis or abscess formation.

This reaction may occur because of the high alkalinity of $\mathrm{Ca}(\mathrm{OH})_{2}$ and may be also interpreted as during the affection of pulp due to caries or 
mechanical trauma, the immune system generates an inflammatory response limiting tissue impairment via removing and consumption of attacking microorganisms and cell debris. These reactions may cause injury to populaces of pulp cells and during the most serious scenarios it may annihilate the entire tooth pulp via the necrosis process ${ }^{(17)}$. These observations were also reported by previous studies ${ }^{(20,22,32)}$. which showed the formation of necrotic layer adjacent to calcium hydroxide, severe inflammation in pulp tissue was observed at one week and the mild pulp inflammation still remained for three weeks.

Another study also showed necrosis of the pulp beneath the layer of calcium hydroxide that was a consistent outcome evident in most of the specimens after 15 days and the arrangement of odontoblasts underneath reparative dentin formed by calcium hydroxide group was not clear ${ }^{(17)}$. However, these results were in contradiction with another study which found that, the inflammatory response to calcium hydroxide group was either absent or of mild intensity and limited to the area immediately beneath the exposure and the layer of odontoblast in close proximity to the exposed area showed regular morphological features ${ }^{(32)}$. This contradiction may be due to the different methodology as they used bur at high speed under water spray coolant but here in the current study inverted-cone carbide bur assembled on low speed micromotor was used and the exposed pulps were sealed with reinforced zinc oxide eugenol above the direct pulp capping material.

For resin composite and its adhesive system containing bioactive glass at 14 days, (40\%) showed small number of inflammatory cells, (50\%) showed number of inflammatory cells infiltrated in the coronal pulp and (70\%) showed discrete pulp disorganization but only (10\%) showed total pulp tissue disorganization. By histologic examination of the area adjacent to the exposure site the pulp tissue revealed some fibrosis, disrupted odontoblastic layer and congested blood vessels (Fig. 14-b). Away from the exposure site, some of the specimens showed hyperemic pulp tissue and normal architecture of odontoblastic layer (Fig. 14-b). These results were in accordance with a study which found that BG causes moderate to severe inflammatory responses at 2 weeks.

Nevertheless, the pulp first showed healing period and subsequently exhibits regular histology at 4 weeks. These results may be an expected protective response from the body to any foreign material, an intense increase in $\mathrm{pH}$ was observed during the 2 hours period, which then plateaued until 14 days and this necrotic layer may protect the dental pulp from irritation such as that caused by high $\mathrm{pH}$ levels; enable the pulp cells to migrate and differentiate into odontoblast like cells, forming reparative dentin ${ }^{(33)}$. The inflammatory response of variable intensities was noticed within both groups during the primary follow-up (fourteen days postoperatively) may be interpreted that the inflamed pulp resulting soon subsequently to treatment is frequently due to mechanical trauma of operative actions and compression during the capping procedure $^{(22,32)}$.

A strong association amongst the pulpal inflammation, tissue disorganization and hard tissue creation has been highlighted by previous studies ${ }^{(17,20)}$. A suggestion stated that the injured and inflamed pulp tissue has inhibited the process of pulpal regeneration $^{(18)}$, as the process of reparative dentinogenesis and complete or partial closure of perforations with dentin bridge was considered good therapeutic result ${ }^{(17)}$.

This association was clear in the current study for the hard tissue formation in both groups, for light cured calcium hydroxide group at 14 days, 90\% showed no hard tissue formation that was observed by histopathological examination (Fig. 15-a). These results were also observed by another study which found that dental pulps capped with calcium hydroxide did not show any signs of early calcification in $71 \%$ of the specimens in the early 
evaluation period ${ }^{(18)}$. However, this was contradicted by others who showed that the calcium hydroxide group exhibited complete dentin bridge formation across the exposure site with fibrodentinal structure at fourteen days ${ }^{(32)}$.This difference may be related to material difference.

For resin composite and its adhesive system containing bioactive glass at fourteen days, fibrous tissue formation was observed under the exposure site which indicates initial dentin bridge formation in some of the specimens (30\%). (Fig. 15-b). This result was reported by another study which showed that slight matrix layer was observed in most samples when direct pulp capping by using BG after mechanical pulp exposures on rat molars at one week ${ }^{(28)}$.

After sixty days, there was a statistically significant difference between the two groups concerning inflammatory cells infiltration and pulp disorganization. This result was highlighted by another study which found that most samples demonstrated normal pulp tissue after 60 days as BAG can induce a healing/ recovery period during which restoration of pulpal morphology is attempted.

This study found that internal resorption was seen in six teeth in $\mathrm{Ca}(\mathrm{OH})_{2}$ group and none in the BAG group concluding that calcium hydroxide seriously impeded the healing process and believed that undifferentiated mesenchymal cells may differentiate into odontoclasts, leading to internal resorption, whereas BAG is biocompatible and can restore pulpal histology. They found abscess which was seen also in five teeth in $\mathrm{Ca}\left(\mathrm{OH}_{22}\right.$ and none in BAG group and referred these results to destroying effect of $\mathrm{Ca}(\mathrm{OH})_{2}$ to the underneath healthful pulp tissue resulting in a layer of necrosis left behind due to its alkaline $\mathrm{pH}$ and deteriorating variations that may occur in the remaining pulp tissue, however BAG has antibacterial property and underlying pulp probably remains vital ${ }^{(30)}$.

For light cured calcium hydroxide group, 30\% showed a quantity of inflammatory cells penetrated into the coronal pulp while $10 \%$ showed necrosis or abscess creation. For pulp tissue disorder of the same group, $40 \%$ showed more widespread pulp disorganization but not completely closing the exposure site while $20 \%$ showed total pulp tissue disorganization. These results coincide with the histopathological examination which showed that adjacent to the exposure site, in most of the specimens, the pulp revealed separated odontoblastic layer (Fig. 15-c).

The remaining pulp tissue showed dense fibrous connective tissue and few dilated blood vessels (Fig. 14-c). In few specimens, the pulp tissue showed diffuse hyalinization and the blood vessels were enlarged, thick walled and filled with coagulated blood. These finding were in accordance with several previous studies which found that, application of a $\mathrm{Ca}(\mathrm{OH})_{2}$-based material was characterized by inflammatory cell infiltration, limited tissue necrosis but partial to complete hard tissue bridging in the longer observation periods ( 65 days $)^{(15,20,31)}$. However, the current results were in contradiction with another study which found that after ninety days, all of the samples of $\mathrm{Ca}(\mathrm{OH})_{2}$ group showed no inflammatory cell response in the pulp ${ }^{(20)}$; which may be due to long observation time or due to the difference in the materials as they used chemical cured $\mathrm{Ca}(\mathrm{OH})_{2}$ as capping material and zinc oxide eugenol above as a restoration.

Inflammation observed (60 days) in the current study for light cured calcium hydroxide group may be caused by the existence of bacteria and it's productions, their introduction occurred due to microleakage across the restoration ${ }^{(31)}$.In addition, every aspect that causes the induction of a continual provocative pulp response after direct pulp capping may result in attracting blood-borne microorganisms' by an anachoretic process, this will consequently result in an unfavorable outcome even after longer peri$\operatorname{ods}^{(20)}$, as that observed in the current study for this group. In this study, (10\%) showed necrosis or abscess formation after sixty days. 
For resin composite and its adhesive system containing bioactive glass at 60 days, $70 \%$ showed no inflammatory cells and $60 \%$ showed normal pulp tissue morphology (Fig. 14-d). It can be inferred that bioactive glass causes a phase of acute inflammation, following which there was a healing/recovery period during which restoration of pulpal morphology was attempted ${ }^{(32)}$. That was in the same line with a study showing that $\mathrm{Ca}$ and $\mathrm{Si}$ released from bioactive glass materials has the ability to stimulate proliferation of osteoblasts and expression of genes and also revealed that human dental pulp cells (HDPCs) in the bioactive glass groups proliferated throughout the culture period confirming that the ions released from bioactive glass at different time intervals did not have an inhibitory effect on cells as assessed by Alamar blue ${ }^{(34)}$.

Moreover, by comparing calcium hydroxide and bioactive glass material as direct pulp capping material, it was found that higher levels of inflammation were observed in calcium hydroxide treated samples, internal resorption and abscess formation, but no internal resorption and abscess formation were observed in bioactive glass applied samples ${ }^{(2)}$.

Concerning dentin bridge formation, after sixty days there was a statistically significant difference between the two groups in the current study. These results were in accordance with previous study which showed formation of dentin bridge in two teeth of calcium hydroxide group and seven teeth of BAG group after 60 days of direct pulp capping with the two materials ${ }^{(30)}$.

By examination of light cured calcium hydroxide group in the current study at 60 days, incomplete dentin bridge was formed in most of the specimens (Fig. 15-c) as 50\% showed hard tissue formation but not completely closing the exposure site while (10\%) only showed hard tissue formation closing the exposure site completely. Dentin bridging was observed in few specimens of light cured calcium hydroxide at 60 days. This result could be interpreted as follows, irreversible injury of odontoblasts caused their replacement with odontoblast-like cells obtained from supplemental pulp cells via a differentiation activity.

Moreover, the amplified alkaline $\mathrm{pH}$ in $\mathrm{Ca}(\mathrm{OH})_{2}$ was associated with the reduction of acidic $\mathrm{pH}$ within inflamed tissue, this decline could be of a great benefit to odontoblast-like cell proliferation, differentiation and migration. In contrast, it was stated that injured endothelial cells is participating in recruiting odontoblast-like cells towards the injury location. The latest odontoblast-like cells produce a tertiary dentin matrix called reparative dentin and the amount of this cell type is considered a critical factor affecting the region of dentin bridge creation ${ }^{(3,18,20)}$. These results of $\mathrm{Ca}(\mathrm{OH})_{2}$ were in accordance also with another study which found that reparative dentin apposition at the perforation site was seen in all of the cases and this newly secreted matrix had a tubular and partially calcified appearance ${ }^{(32)}$.

For resin composite and its adhesive system containing bioactive glass at 60 days, there was statistically significant difference between the two groups, $60 \%$ showed complete dentin bridge formation that was observed by histologic examination (Fig. 15-d). This observation may be due to the normal architecture of odontoblastic layer that was seen in some specimens. Likely that these cells are not true odontoblasts, but odontoblast like cells, These cells, similarly to true odontoblasts have elongated shape, palisade orientation and basal nucleus alignment and have the ability to produce extracellular matrix that after mineralization becomes complete or incomplete dentin bridge or islands that tend to establish contact with side dentin walls to close and preserve exposed pulp ${ }^{(17)}$.

Moreover, the particle size of nano bioactive glass particles used in this study had a length of about 50 to $100 \mathrm{~nm}$ similar to biologic apatite found in the human dentin ${ }^{(33)}$. Additionally, the presence of atubular dentin has been found to provide a "barrier effect" against penetration of noxious agents (Fig. 15-d). It was also speculated that the 
initially formed atubular dentin or osteodentin can become progressively lined with tubules forming tubular dentin ${ }^{(35)}$. Also, it was established that BG showed better ability to form tubular dentin bridge over the exposed pulp when compared to light cured calcium hydroxide ${ }^{(33)}$.

This significant difference could be also due to the porosity of the formed reparative dentin having tunnel defects that was formed by calcium hydroxide which fail to provide a hermetic seal to the underlying pulp against bacterial leakage ${ }^{(32)}$. Bioactive glass particles induced the compact reparative dentin having regular arrangement of odontoblasts and dentinal tubules. This accounts for the quality difference of reparative dentin formed between bioactive glass and calcium hydroxide ${ }^{(36)}$.

Finally, the null hypothesis tested in this study, that there was no difference in the response of dogs, teeth (in terms of inflammatory cell infiltrate, pulp tissue disorganization and dentin bridge formation) to bioactive glass nanoparticles incorporated in resin composite restoration and its adhesive when compared with light cured calcium hydroxide was rejected as there was a statistically significant difference between both materials after sixty days.

\section{CONCLUSIONS}

Within the limitations of the present study, the following conclusions could be drawn:

1. Bioactive glass nanoparticles incorporated in resin composite and its adhesive appears to be promising in inducing favorable pulpal response and enhancing the reparative capacity of the pulp.

2. Bioactive glass nanoparticles could be considered as a potential material for direct pulp capping.

3. Bioactive glass successfully stimulated the mineralization and dentin bridge formation thus could be considered as potential pulp capping material replacing light cured calcium hydroxide.

\section{REFERENCES}

1. Sauro S, Babbar A, Gharibi B, Feitosa VP, Carvalho RM, Azevedo Rodrigues LK, et al. Cellular differentiation, bioactive and mechanical properties of experimental light-curing pulp protection materials. Dent Mater. 2018; 34:868-78.

2. Aidaros NH, Niazy MA, El-yassaky MA. The Effect of Incorporating Nanocalcium Phosphate Particles into Biodentin on Pulpal Tissue Response (In Vitro Study). AlAzhar Dent J Girls. 2018;5:181-6.

3. Sirikonda S, Sravanthi D, Swetha K, Ankireddy S, Shereen S, Manra M, et al. Comparative efficacy of calcarea phosphorica versus calcium hydroxide materials for the disinfection of remaining carious dentin in deep cavities: An In vivo study. Indian J Dent Sci. 2020; 1:12-21.

4. Khvostenko D, Hilton TJ, Ferracane JL, Mitchell JC, Kruzic JJ. Bioactive glass fillers reduce bacterial penetration into marginal gaps for composite restorations. Dent Mater. 2016; 32:73-81.

5. Wang S, Hu Q, Gao X, Dong Y. Characteristics and effects on dental pulp cells of a polycaprolactone/submicron bioactive glass composite scaffold. J Endod. 2016;42:1070-5.

6. Narayana S, Deepa V, Ahamed S, Sathish E, Meyappan R, Satheesh Kumar K. Remineralization efficiency of bioactive glass on artificially induced carious lesion an in-vitro study. J Indian Soc Pedod Prev Dent. 2014; 32:19-25.

7. Lee JH, Seo SJ, Kim HW. Bioactive glass-based nanocomposites for personalized dental tissue regeneration. Dent Mater J. 2016; 35:710-20.

8. Fayyad D, ElBaz G. Comparative Evaluation of Bioactive Materials and Their Nano-Counterpart as Pulp Capping Agents in Dogs' Teeth. Egypt Dent J. 2018; 64:9-22.

9. Par M, Tarle Z, Hickel R, Ilie N. Mechanical properties of experimental composites containing bioactive glass after artificial aging in water and ethanol. Clin Oral Investig. 2019; 23:2733-41.

10. Par M, Spanovic N, Bjelovucic R, Skenderovic H, Gamulin $\mathrm{O}$, Tarle Z. Curing potential of experimental resin composites with systematically varying amount of bioactive glass: Degree of conversion, light transmittance and depth of cure. J Dent. 2018; 75:113-20.

11. Jeya Gopika G, Ramarao S, Usha C, John BM, Vezhavendhan N. Histological evaluation of human pulp capped with light-cured calcium-based cements: a randomized controlled clinical trial. Int J Sci Reports. 2017; $3: 120-7$. 
12. Salehi S, Gwinner F, Mitchell JC, Pfeifer C, Ferracane JL. Cytotoxicity of resin composites containing bioactive glass fillers. Dent Mater. 2015; 31:195-203.

13. Carneiro KK, Araujo TP, Carvalho EM, Meier MM, Tanaka A, Carvalho CN, et al. Bioactivity and properties of an adhesive system functionalized with an experimental niobium-based glass. J Mech Behav Biomed Mater. 2018; 78:188-95.

14. Delihta J, Fernando L. Mesoporous N, Glasses B. Novel Mesoporous Bioactive Glasses (MBGs) as fillers in dental adhesives "Synthesis, Physico-chemical and biological evaluation". Biomaterials. 2018; 76:1369-77.

15. Akhavan A, Arbabzadeh F, Bouzari M, Razavi SM, Davoudi A. Pulp response following direct pulp capping with dentin adhesives and mineral trioxide aggregate; an animal study. Iran Endod J. 2017; 12:226-30.

16. Salah S. Biological response of nanohydroxyapetite as a direct pulp capping material individually or combined with silver or low-level laser therapy. PHD thesis, Al-Azhar University. 2017.

17. Popović-Bajić M, Petrović V, Opačić-Galić V, Danilović V, Jokanović V, Prokić B, et al. Direct pulp capping with novel nanostructural materials based on calcium silicate systems and hydroxyapatite. Stomatol Glas Srb. 2016; 63: 183-92.

18. Zaen El-Din AM, Hamama HH, Abo El-Elaa MA, Grawish ME, Mahmoud SH, Neelakantan P. The effect of four materials on direct pulp capping: An animal study. Aust Endod J. 2020; 3:1-8.

19. Negm AM, Hassanien EE, Abu-Seida AM, Nagy MM. Biological evaluation of a new pulp capping material developed from Portland cement. Exp Toxicol Pathol. 2017; 69:115-22.

20. Poimenova A, Kitraki E, Kakaboura A, Rahiotis C. Early responses of human pulp to direct capping with resin adhesive systems and calcium hydroxide. Dent Mater. 2018; 34:73-82.

21. Par M, Tarle Z. Bioactive dental composite materials. Rad Hrvat Akad Znan i Umjet Med Znan. 2018; 45:83-99.

22. Kamal EM, Nabih SM, Obeid RF, Abdelhameed MA. The reparative capacity of different bioactive dental materials for direct pulp capping. Dent Med Probl. 2018; 55:147-52.

23. Abbasi Z, Bahroloolum ME, Shariat MH, Bagheri R. Bioactive Glasses in Dentistry: A Review. J Glas Dent A Rev. 2015; 2:1-9.

24. Jang JH, Lee MG, Ferracane JL, Davis H, Bae HE, Choi D, et al. Effect of bioactive glass-containing resin composite on dentin remineralization. J Dent. 2018; 75:58-64.
25. Bauer J, Carvalho EM, Carvalho CN, Meier MM, Souza JP de, Carvalho RM de, et al. Development of a simplified etch-and-rinse adhesive containing niobiophosphate bioactive glass. Int J Adhes. 2016; 69:110-4.

26. Pintado-Palomino K, de Almeida CVVB, da Motta RJG, Fortes JHP, Tirapelli C. Clinical, double blind, randomized controlled trial of experimental adhesive protocols in caries-affected dentin. Clin Oral Investig. 2019; 23:1855-64.

27. Syed MR, Khan M, Sefat F, Khurshid Z, Zafar MS, Khan AS. Bioactive Glass and Glass Fiber Composite: Biomedical/Dental Applications. Biomedical, Therapeutic and Clinical Applications of Bioactive Glasses. Elsevier Ltd.; 2019; 44: 467-95.

28. Eliwa M, Niazy M, Farouk H, Mostafa A. The Remineralizing Effect of Incorporating Ca-Phosphate and Ca-Fluoride Nanoparticles into the Self-Etch Adhesives Used in Restoring Class I Cavities. Al-Azhar Dent J Girls. 2019; 5:181-6.

29. Long Y,Liu S, Zhu L, Liang Q, Chen X, Dong Y. Evaluation of Pulp Response to Novel Bioactive Glass Pulp Capping Materials. J Endod. 2017; 43:1647-50.

30. Jun SK, Lee JH, Lee HH. The Biomineralization of a Bioactive Glass-Incorporated Light-Curable Pulp Capping Material Using Human Dental Pulp Stem Cells. Biomed Res Int. 2017; 2017:1-9.

31. Haghgoo R, Asgary S, Montazeri R. Histopathological Evaluation of Primary Teeth after Pulp Capping with Calcium-Enriched Mixture and Bioactive Glass. Iran Endod J. 2018; 13:457-60.

32. Al-Saudi KW, Nabih SM, Farghaly AM, AboHager EAA. Pulpal repair after direct pulp capping with new bioceramic materials: A comparative histological study. Saudi Dent J. 2019; 31:469-75.

33. Hussain SS. Evaluation of pulpal and dentin regeneration by different pulp-capping materials using mouse model. Master thesis, 2019;1-23.

34. Hanada K, Morotomi T, Washio A, Yada N, Matsuo K, Teshima $\mathrm{H}$, et al. In vitro and in vivo effects of a novel bioactive glass-based cement used as a direct pulp capping agent. J Biomed Mater Res - Part B Appl Biomater. 2019; 107:161-8.

35. Kim GH, Park YD, Lee SY, El-Fiqi A, Kim JJ, Lee EJ, et al. Odontogenic stimulation of human dental pulp cells with bioactive nanocomposite fiber. J Biomater Appl. $2015 ; 29: 854-66$.

36. Gholami S, Labbaf S, Houreh AB, Ting HK, Jones JR, Nasr Esfahani $\mathrm{MH}$. Long term effects of bioactive glass particulates on dental pulp stem cells in vitro. Biomed Glas. 2017; 3:96-103. 